\title{
Sexual Dimorphism in Permanent Maxillary Central Incisor in Kosovo - Albanian Population
}

\author{
Dimorfismo Sexual en los Incisivos Centrales Superiores \\ Permanentes en una Población Albanesa de Kosovo
}

Gloria Staka*; Flurije Asllani-Hoxha* \& Venera Bimbashi***

STAKA, G.; ASLLANI-HOXHA, F. \& BIMBASHI, V. Sexual dimorphism in permanent maxillary central incisor in Kosovo - Albanian population. Int. J. Morphol., 34(3):1176-1180, 2016.

SUMMARY: The aim of this study was to investigate the sexual dimorphism in permanent maxillary central incisor in Kosovo Albanian population using crown linear diameters, crown module (CM) and crown index (CI). The study sample consisted of 204 dental students, selected from the Dental School, Faculty of Medicine at University of Prishtina, Republic of Kosovo. The measurements of mesiodistal (MD) and buccolingual (BL) crown diameters of left and right permanent maxillary incisor (MCI) were taken in a dental casts using electronic digital caliper Boss, Hamburg - Germany, with accuracy $\pm 0.01 \mathrm{~mm}$. The descriptive statistics, t-test and percentage of sexual dimorphism in crown linear diameters and dental indexes of maxillary central incisor were calculated. The results showed a statistically significant difference in $\mathrm{MD}(\mathrm{p}<0.01)$ and BL diameters $(\mathrm{p}<0.0001)$ of maxillary central incisor between males and females. BL diameter of maxillary central incisor showed greater sexual dimorphism (4.78\%) than mesiodistal diameter $(2.76 \%)$. CM presented with a higher level of sexual dimorphism $(3.76 \%)$ comparing to CI $(1.89 \%)$. The findings of this study demonstrated sexual dental dimorphism in crown linear diameters and dental indexes in maxillary central incisor in Kosovo-Albanian population.

KEY WORDS: Maxillary Central Incisor; Crown Linear Diameters; Dental Indexes; Sexual Dimorphism; KosovoAlbanian Population.

\section{INTRODUCTION}

Teeth are known to be unique organs made of the most enduring mineralized tissues in the human body. As such, teeth are extraordinary resistance to putrefaction and the effect of physical, thermal, mechanical, chemical or biological types of destruction (Astete et al., 2009). They are the hardest tissue in the human body, an excellent material in living and non living populations for anthropological, genetic, odontologic, evolutionary and forensic investigation (Williams et al., 1995).

The tooth crown size is a valuable tool and provides significant information on human evolution (Plavcan, 2001) biological alternations (Garn, 1979), in forensic evaluation (Karaman, 2006) and clinical odontology (Hattab et al., 1996). Tooth size is affected by cultural, environmental, racial and genetic factors (Joseph et al., 2013). Is standards based on odontometrics investigation can be used in age and sex determination (Vodanovic et al., 2007).
Dental measurements are important in anthropology for the study of sexual dimorphism, the trend toward tooth and jaw size reduction Late Pleistocene/ Early Holocene humans and difference between past human populations (Hillson et al., 2005).

Sexual dimorphism refers to those differences in size, structure and appearance between male and female, at an equal age, which can be applied to dental identification, because no two oral cavities are identical (Kieser, 1990). The sexual dimorphism is more pronounced in permanent dentition than in deciduous teeth. The magnitude and pattern of sexual dimorphism in the size of permanent teeth also differ from one population to another (Garn et al., 1979).

The two most commonly used and researched features in determining sex based on dental measurements are the mesiodistal (MD) and buccolingual (BL) crown diameters of

\footnotetext{
* Department of Prosthodontics, Dental School, Faculty of Medicine, University of Prishtina, and University Dentistry Clinical Center of Republic of Kosovo. ** Department of Prosthodontics, Dental School, Faculty of Medicine, University of Prishtina, Republic of Kosovo.
} 
the permanent teeth (Iscan \& Kedici, 2003). Sexual dimorphism in tooth size has been explored focusing on the use of $\mathrm{BL}$ and $\mathrm{MD}$ diameter - termed linear measurements. Recently, diagonal measurements of the tooth crowns were used in sex determination (Karaman). An option which could prove useful in sex determination is the calculations of dental indexes, which derived from simple mathematical combinations of linear measurement (Acharya \& Mainali, 2008). Dental indexes include crown index (CI), crown module (CM) and crown area (CA) (Hillson, 1996). The mandibular canines traditionally exhibit the greatest sexual dimorphism (Zorba et al., 2011). Premolars, first and second molars as well maxillary incisors are also known to have significant differences (Acharya \& Sivapathasundharam, 2009).

As sexual dimorphism varies between different populations and the collection of population specific data is of major importance (Zorba et al.). There are no data for crown linear diameters and dental indexes of maxillary central incisor in Kosovo Albanian population.

The aim of this study was to assess the degree of sexual dimorphism in maxillary central incisor in Kosovo Albanian population using crown linear diameters, crown module and crown index.

\section{MATERIAL AND METHOD}

The study sample consisted of 204 dental students, selected from the Dental School, Faculty of Medicine, University of Prishtina. The research was approved by the Institutional Ethic Committee. Written informed consent was taken prior to the investigation after detailed information given to the participants regarding the study. The subjects were selected based on inclusion criteria outlined in the beginning of this study.

Inclusion criteria:

1. Parents and grandparents of Kosovo-Albanian origin

2. Age between $18-25$ years

3. Completed set fully erupted and morphological well formed teeth

4. Non carious teeth

5. Non attrited teeth

6. Intact and periodontally healthy teeth

7. Satisfactory aligned maxillary teeth, with no spacing or diastema and no crowding

8. With no history or clinical evidence of crown restoration, orthodontic treatment and trauma.

The measurements of mesiodistal (MD) and buccolingual (BL) crown diameters of both, right and left permanent maxillary incisor (MI) were taken in a dental casts using electronic digital caliper Boss, Hamburg - Germany, with an accuracy $\pm 0.01 \mathrm{~mm}$. The mesiodistal crown diameter was defined as the greatest mesiodistal dimension, taken parallel to the occlusal and facial surface (Morreess \& Reed, 1964) The buccolingual crown diameter was defined as the greatest distance between the buccal (or labial) and lingual (or palatinal) surfaces of the crown, perpendicular to the mesiodistal diameter (Morreess \& Reed). Measurements were done by a single examiner (G.S) to eliminate interobserver error. Each measurement was taken three times and the average of the three values was noted to minimize the intra-observer error.

Dental indexes were calculated from MD and BL measurements of maxillary central incisor according to the formula given by Hillson.

$$
\begin{aligned}
& C M=\frac{M D+B L}{2} \\
& C I=\frac{100 \times B L}{M D}
\end{aligned}
$$

All statistical analysis was carried out with the SPSS 19 for Windows (SPSS Inc., Chicago, Illinois, USA) and MS Excel (Microsoft Office, Windows 2007, USA). Mean standard deviation (SD), range, coefficient of variation (CV), percentage of sexual dimorphism and dental indexes were calculated. The statistical significance of differences in MD, $\mathrm{BL}, \mathrm{CI}$ and $\mathrm{CM}$ between males and females was calculated using $\mathrm{t}$ test for independent samples with $\mathrm{p}<0.01$ and $\mathrm{p}<0.05$.

Percentage of sexual dimorphism in crown linear diameters and dental indices of maxillary central incisor was calculated according to the formula (Garn et al.).

$$
\text { Sexual dimorphism }=[\mathrm{Xm} / \mathrm{Xf}]-1 \times 100
$$

$\mathrm{Xm}=$ mean value for males; $\mathrm{Xf}=$ mean values for females

\section{RESULTS}

The overview of descriptive statistics (mean, range, standard deviation and coefficient of variation), $t$ - values and P-values for MD, BL, CI and CM for maxillary central incisor are accessible in Tables I, II, III and IV. In males the mean value for MD diameter was $8.56 \mathrm{~mm}$ and in females $8.33 \mathrm{~mm}$ (Table I). MD diameter of maxillary central incisor showed a statistically significant differences between males 
and females $(\mathrm{p}<0.01)$. The mean values of BL diameter in males was $7.45 \pm 0.48 \mathrm{~mm}$ and in females $7.11 \pm 0.50$ (Table II). There was a statistically significant difference between males and females in BL diameters of maxillary central incisor ( $\mathrm{p}<0.0001)$. A statistically significant difference was confirmed between males and females in CI and CM of maxillary central incisor (Table III and IV).

The percentage (\%) of sexual dimorphism in MD and BL diameter, CI and CM of maxillary central incisor are presented in Table V. It was observed that the most dimorphic odontometric features was BL $(4.78 \%)$ followed by, CM (3.76 \%), MD $(2.76 \%)$ and $\mathrm{CI}(1.89 \%)$.

Table I. Descriptive statistics and t- value of MD diameter of maxillary central incisor.

\begin{tabular}{lcccccc}
\hline Sex & N & $\begin{array}{c}\text { Mean } \pm \text { SD } \\
(\mathbf{~ m m})\end{array}$ & Range & $\mathbf{9 5 \% C I}$ & CV\% & p-value \\
\hline Male & 101 & $8,56 \pm 0,49$ & $7,23-9,76$ & $8,47-8,66$ & 5.73 & $\mathrm{t}=3.217$ \\
Female & 103 & $8,33 \pm 0,53$ & $7,13-9,89$ & $8,23-8,43$ & 6.31 & $\mathrm{p}<0.01$ \\
Total & 204 & $8,45 \pm 0,52$ & $7,13-9,89$ & $8,35-8,55$ & 6.16 & \\
\hline
\end{tabular}

Table II. Descriptive statistics and t- value of BL diameter of maxillary central incisor.

\begin{tabular}{lcccccc}
\hline Sex & $\mathbf{N}$ & $\begin{array}{c}\text { Mean } \pm \text { SD } \\
(\mathbf{~ m m})\end{array}$ & Range & $\mathbf{9 5 \% C I}$ & $\mathbf{C V} \%$ & p-value \\
\hline Male & 101 & $7,45 \pm 0,48$ & $6,24-8,63$ & $7,36-7,54$ & 6.43 & $\mathrm{t}=4.95$ \\
Female & 103 & $7,11 \pm 0,50$ & $6,00-8,29$ & $7,02-7,21$ & 7.00 & $\mathrm{p}<0.0001$ \\
Total & 204 & $7,28 \pm 0,52$ & $6,00-8,63$ & $7,18-7,38$ & 7.09 & \\
\hline
\end{tabular}

Table III. Descriptive statistics and t-value of CI for maxillary central incisor.

\begin{tabular}{lcccccc}
\hline Sex & $\mathbf{N}$ & $\begin{array}{c}\text { Mean } \pm \text { SD } \\
(\mathbf{~ m m})\end{array}$ & Range & $\mathbf{9 5 \% C I}$ & $\mathbf{C V \%}$ & p-value \\
\hline Male & 101 & $87.17 \pm 5.51$ & $74.76-102.29$ & $86.11-88.24$ & 6.32 & $\mathrm{t}=2.06$ \\
Female & 103 & $85.55 \pm 5.70$ & $75.52-103.71$ & $84.45-86.66$ & 6.66 & $\mathrm{p}<0.05$ \\
Total & 204 & $86.36 \pm 5.65$ & $74.76-103.71$ & $85.26-87.46$ & 6.54 & \\
\hline
\end{tabular}

Table IV. Descriptive statistics and t-value of CM for maxillary central incisor.

\begin{tabular}{lcccccc}
\hline Sex & $\mathbf{N}$ & $\begin{array}{c}\text { Mean } \pm \mathbf{S D} \\
\mathbf{( ~ m m ~})\end{array}$ & Range & $\mathbf{9 5 \%} \mathbf{C I}$ & $\mathbf{C V \%}$ & p-value \\
\hline Male & 101 & $8.01 \pm 0.41$ & $6.97-9.02$ & $7.93-8.09$ & 5.18 & $\mathrm{t}=4.8$ \\
Female & 103 & $7.72 \pm 0.45$ & $6.74-9.08$ & $7.64-7.81$ & 5.77 & $\mathrm{p}<0.0001$ \\
Total & 204 & $7.86 \pm 0.45$ & $6.74-9.08$ & $7.78-7.95$ & 5.75 & \\
\hline
\end{tabular}

Table V. Percentage of sexual dimorphism in MD, BL, CI and CM of maxillary central incisor.

\begin{tabular}{llll}
\hline $\begin{array}{l}\text { Maxillary } \\
\text { central incisor }\end{array}$ & Males & Females & $\begin{array}{c}\text { \% } \\
\text { Dimorphis }\end{array}$ \\
\hline MD & $8.56 \pm 0.49$ & $8.33 \pm 0.53$ & 2.76 \\
BL & $7.45 \pm 0.48$ & $7.11 \pm 0.50$ & 4.78 \\
CI & $87.17 \pm 5.51$ & $85.55 \pm 5.70$ & 1.89 \\
CM & $8.01 \pm 0.41$ & $7.72 \pm 0.45$ & 3.76 \\
\hline
\end{tabular}

\section{DISCUSSION}

The general structure and morphology of the teeth are similar in male and female; however, there are subtle differences, such as variation in dental size that can be indicators of the differences between the sexes (Sabóia et al., 2013). The use of dental morphology to determine sexual dimorphism is a procedure established in anthropological and biological studies especially in forensic odontology, it determines sex from fragmented jaws and dentition (Vodanovic et al.).

The present study established normative data of the $\mathrm{MD}, \mathrm{BL}, \mathrm{CI}$ and $\mathrm{CM}$ of the maxillary central incisor and recognize significant sexual dimorphism among KosovoAlbanian population aged between 18-25 years.

The MD and BL crown diameters of left and right maxillary central incisor were measured on dental cast. Measurements on dental cast are straight forward and credible (Hunter \& Priest, 1960). Crown index and crown module of the maxillary central incisor was calculated using the crown linear diameters. In our findings there was no significant difference between measurements of left and right maxillary central incisor, similar to other previous reported studies; samples of three populations from Egypt, Mexico and United States (Bishara et al., 1989) in Saudi Arabian (Al-Rifaiy et al., 1997) and in Brazilian population (da Costa et al., 2012). The current study confirms the statistically significant difference in $\mathrm{MD} \quad(\mathrm{p}<0.01)$ and $\mathrm{BL}$ $(p<0.0001)$ of maxillary central 
incisor between males and females. Our findings were in agreement with the studies done by other authors, where they have observed that males had larger teeth than females in all dimensions (Sabóia et al.; Nahidh, 2014; Srivastav et al., 2014) and sexual dimorphism is more pronounced in BL than in MD diameter (Yamada \& Sakai, 1992). Crown indexes for maxillary central incisor were also greater in males than in females with significant differences for $\mathrm{CI}(\mathrm{p}<0.05)$ and $\mathrm{CM}(\mathrm{p}<0.0001)$.

The percentage of sexual dimorphism was calculated for MD, BL, CI and CM. The BL diameter of maxillary central incisor showed a larger percentage of sexual dimorphism $(4.78 \%)$ than the MD $(2.76 \%)$. It was found that the difference between males and females in the percentage of dental sexual dimorphism ranged from 3-9 \% (Kieser). BL crown diameter are more dismorphic than MD diameter in most population (Zorba et al.). Relating all the facts and the results of the previous studies we have an inference that some studies show that BL dimension has more sex determination potential (Iscan \& Kedici) and other proved that MD is better sex predictor (Astete et al.). Hence, for sex prediction it's preferred to analyze both linear dimensions rather than choosing a single dimension. CM showed a high rate of sexual dimorphism $(3.76 \%)$ than CI $(1.89 \%)$.

The different patterns of sexual dental dimorphism observed between different population reflect genetic, epigenetic and environmental influences to dental development (Srivastav et al.). As there are differences in odontometric features in specific populations, even within the same population in the historical and evolutionary context, it is necessary to determine specific population values in order to make identification possible on the basis of dental measurements (Iscan \& Kedici).

Different human populations showed different expressions of sexual dimorphism. In some populations, this dimorphism may be more developed than in others. Sexual dimorphisms in tooth size are population specific (Iscan \& Kedici) and varied among different ethnic groups (Garn et al.).

It should be noted that this study included few limitations. Objective of limiting the sample of young adults was to reduce the influence of tooth wear and attrition on tooth measurements.

\section{CONCLUSIONS}

This study demonstrated the sexual dental dimorphism in crown linear diameters and dental indexes in maxillary central incisor in Kosovo-Albanian population. Maxillary central incisor can be used in forensic investigations as an adjunct along with other accepted procedures for sex determination.

\section{ACKNOWLEDGMENTS}

The authors would like to thank all students from the Dental School, Medical Faculty University of Prishtina, for support, patience and participation in this study.

STAKA, G.; ASLLANI-HOXHA, F. \& BIMBASHI, V. El dimorfismo sexual en los incisivos centrales superiores permanentes en una población albanesa de Kosovo. Int. J. Morphol., 34(3):1176-1180, 2016.

RESUMEN: El objetivo de este estudio fue investigar el dimorfismo sexual en el diente incisivo central superior permanente en una población albanesa de Kosovo utilizando diámetros lineales de las copas, módulo de corona (MC) y el índice de la corona (IC). La muestra del estudio consistió en 204 estudiantes de odontología, seleccionados de la Escuela de Odontología, Facultad de Medicina de la Universidad de Pristina, República de Kosovo. Se tomaron mediciones mesiodistales (MD) y diámetros bucolinguales (BL) de la corona de los dientes incisivos superiores permanentes izquierdo y derecho, en modelos dentales, utilizando un calibrador digital electrónico Boss (Hamburgo - Alemania) con una precisión de $\pm 0,01 \mathrm{~mm}$. Se calculó la estadística descriptiva, t-test y porcentaje de dimorfismo sexual en los diámetros lineales de coronas dentales y los índices del diente incisivo central superior. Los resultados mostraron una diferencia estadísticamente significativa en $\mathrm{MD}(\mathrm{p}<0,01)$ y diámetros BL $(\mathrm{p}<0,0001)$ del diente incisivo central superior entre hombres y mujeres. Se observó un mayor dimorfismo sexual $(4,78 \%)$ en el diámetro BL del diente incisivo central superior, que en el diámetro mesiodistal (2,76 \%). El MC presentó un nivel mayor de dimorfismo sexual (3,76 \%) en comparación con IC (1,89\%). Los resultados de este estudio demostraron la existencia de dimorfismo sexual en los diámetros lineales de la corona dental y de los índices dentales correspondientes al diente incisivo central superior en la población albanesa de Kosovo.

PALABRAS CLAVE: Diente incisivo maxilar central; Diámetros lineales de la corona; Índices dentales; Dimorfismo sexual; Población albanesa - Kosovo. 


\section{REFERENCES}

Acharya, A. B. \& Mainali, S. Are dental indexes useful in sex assessment? J. Forensic. Odontostomatol., 27(2):53-9, 2008.

Acharya, A. B. \& Sivapathasundharam, B. Forensic Odontology. In: Rajendran, R. \& Sivapathasundharam, B. (Eds.). Shafer's Textbook of Oral Pathology. 6th ed. Noida, Elsevier, 2009. pp.880-2.

Astete, J. C.; San Pedro Valenzuela, J. \& Suazo Galdames, I. Sexual dimorphism in the tooth dimensions of Spanish and Chilean peoples. Int. J. Odontostomatol., 3(1):41-50, 2009.

Al-Rifaiy, M. Q.; Abdullah, M. A.; Ashraf, I. \& Khan. N. Dimorphism of mandibular and maxillary canine teeth in establishing sex identity. Saudi Dent. J., 9(1):17-20, 1997.

Bishara, S. E.; Jakobsen, J. R.; Abdallah, E. M. \& Fernandez Garcia, A. Comparisons of mesiodistal and buccolingual crown dimensions of the permanent teeth in three populations from Egypt, Mexico, and the United States. Am. J. Orthod. Dentofacial Orthop., 96(5):416-22, 1989.

da Costa, Y. T. F.; Lima, L. N. C. \& Rabello, P. M. Analysis of canine dimorphism in the estimation of sex. Braz. J. Oral Sci., 11(3):406-10, 2012.

Garn, S. M.; Osborne, R. H. \& McCabe, K. D. The effect of prenatal factors on crown dimensions. Am. J. Phys. Anthropol., 51(4):665-78, 1979.

Garn, S. M.; Lewis, A. B.; Swindler, D. R. \& Kerewsky, R. S. Genetic control of sexual dimorphism in tooth size. J. Dent. Res., 46(5):963-72, 1967.

Hattab, F. N.; al-Khateeb, S. \& Sultan, I. Mesiodistal crown diameters of permanent teeth in Jordanians. Arch. Oral. Biol., 41(7):641-5, 1996.

Hillson, S.; Fitzgerald, C. \& Flinn, H. Alternative dental measurements: proposals and relationships with other measurements. Am. J. Phys. Anthropol., 126(4):413-26, 2005.

Hillson, S. Dental Anthropology. Cambridge, Cambridge University Press, 1996. pp.72.

Hunter, W. S. \& Priest, W. R. Errors and discrepancies in measurement of tooth size. J. Dent. Res., 39:405-14, 1960.

Iscan, M. Y. \& Kedici, P. S. Sexual variation in bucco-lingual dimensions in Turkish dentition. Forensic. Sci. Int., 137(23):160-4, 2003.

Joseph, A. P.; Harish, R. K.; Mohammed, P. K. R. \& Vinod Kumar, R. B. How reliable is sex differentiation from teeth measurements. Oral Maxillofac. Pathol. J., 4(1):289-92, 2013.
Karaman, F. Use of diagonal teeth measurements in predicting gender in a Turkish population. J. Forensic. Sci., 51(3):630-5, 2006.

Kieser, J. A. Human Adult Odontometrics. The Study of Variation in Adult Tooth Size. Cambridge, Cambridge University Press, 1990.

Moorrees, C. F. \& Reed, R. B. Correlations among crown diameters of human teeth. Arch. Oral. Biol., 9:685-97, 1964.

Nahidh, M. The value of maxillary central incisors and canines in gender determination as an aid in forensic dentistry. Iraqi. Dent. J., 36(1):8-12, 2014.

Plavcan, J. M. Sexual dimorphism in primate evolution. Am. J. Phys. Anthropol., Suppl. 33:25-53, 2001.

Sabóia, T. M.; Tannure, P. N.; Luiz, R. R.; Costa, M. C.; Granjeiro, J. M.; Küchler, E. C. \& Antunes, L. S. Sexual dimorphism involved in the mesiodistal and buccolingual dimensions of permanent teeth. Dentistry 3000, 1(1), 2013.

Srivastava, R.; Jyoti, B.; Jha, P.; Gupta, M.; Devi, P. \& Jayaram, R. Gender determination from the mesiodistal dimension of permanent maxillary incisors and canines: An odontometric study. J. I. A. O. M. R., 26(3):287-92, 2014.

Vodanovic', M.; Demo, Z.; Njemirovskij, V.; Keros, J. \& Brkic', H. Odontometrics: a useful method for sex determination in an archaeological skeletal population? J. Archaeol. Sci., 34(6):905-13, 2007.

Williams, P. L. \& Bannister, L. H. Gray's Anatomy. The Anatomical Basis of Medicine \& Surgery. New York, Churchill Livingstone, 1995.

Yamada, H. \& Sakai, T. Sexual Dimorphism in Tooth Crown Diameters of the Cook Islanders. In: Smith, P. \& Tchernov, E. (Eds.). Structure, Function and Evolution of Teeth. London, Freund Publishing House Ltd., 1992. pp.437-49.

Zorba, E.; Moraitis, K. \& Manolis, S. K. Sexual dimorphism in permanent teeth of modern Greeks. Forensic Sci. Int., $210(1-$ 3):74-81, 2011.

\section{Correspondence to:}

Venera Bimbashi

Department of Prosthodontics

Dental School, Faculty of Medicine

University of Prishtina

Rrethi i Spitalit p.n. 10000

Prishtina

REPUBLIC OF KOSOVO

Email: vbimbashi@gmail.com 